MARTIN NEIL BAILY

University of Maryland

CHARLES L. SCHULTZE

Brookings Institution

\title{
The Productivity of Capital in a Period of Slower Growth
}

The United STATES has invested a smaller fraction of its gross national product in capital goods than almost any of its major international competitors in the 40 years since 1948 . Over this same period, average labor productivity growth in the United States has also been among the slowest. For the first 25 years of the period there was little cause for dissatisfaction. U.S. productivity growth was higher than it was in the prewar years, and the still higher rates in Europe could easily be explained as a catch-up phenomenon. But after 1973 U.S. labor productivity growth fell to only a little more than 1 percent a year, and in the past five years net investment has dropped substantially.

Many people have argued that increasing the level of physical investment in the U.S. economy would have a large payout in higher productivity growth. We agree that investment should be increased, but we suspect that the potential productivity improvements are being exaggerated. The issue is important both for economic analysis and for economic policy. If the growth payoff from increasing the capital stock is large, economic policy can concentrate on raising national saving and investment. If the payoff is small, the nation would be wise to bend some of its efforts toward other means of improving productivity growth. From the perspective of economic analysis, we want to know how to

An earlier version of this paper was presented at the National Bureau of Economic Research productivity group meeting, December 4, 1989. The authors would like to thank Steven H. Fagin and Allen L. Sebrell for research assistance and participants in the Brookings panel meeting and the NBER meeting for helpful comments. 
build growth models that do well in tracking past growth and help us predict the likely future path of output and productivity in the economy.

Our assessment of both theory and policy will take into account the slowdown in productivity growth in the past 20 years. If technology or other growth-promoting factors are advancing more slowly, then increased investment may be the chief way available to increase productivity growth at a time when other sources of growth seem to have burned out. ${ }^{1}$ Raising the level of capital intensity above the current level under those circumstances, however, means accepting a lower rate of return on new investment.

We start by assessing whether the simple neoclassical model of economic growth that lay behind those earlier estimates has been supported by the pattern of actual economic growth. Of particular importance is whether there is evidence to support recent theoretical models challenging the neoclassical model's conclusion that capital's effect on productivity is small. In the 1950s and 1960s, writers such as Moses Abramovitz, Edward Denison, John Kendrick, and Robert Solow developed empirical estimates that indicated that the contribution of physical capital to the growth in average labor productivity (measured by inflation-adjusted output per hour) was surprisingly small. ${ }^{2}$ The question is whether these estimates need to be revised upward on the basis of subsequent developments in theory and empirical analysis. On the theoretical side, recent work has assumed capital externalities or increasing returns to capital-investment by one firm increases productivity in other firms. These models thus imply that the share of capital income in total income understates the capital elasticity (the percentage change in output from a given percentage increase in capital input).

Next we look at two empirical studies, one by Dale Jorgenson and one by Edward Denison, that have refined the data and methods of the simple growth model and reached very different conclusions about the contribution of capital to growth. We then ask under what conditions capital can boost growth by embodying new technology. Finally, we see how market imperfections may affect capital share estimates.

To summarize our conclusions, we find that the simple neoclassical growth model does reasonably well in tracking longer-term swings in

1. Dertouzos, Lester, and Solow (1989).

2. Abramovitz (1956); Denison (1962); Kendrick (1961); and Solow (1957). 
U.S. growth rates. We also find direct support for a key feature of this model that has been challenged by the recent theoretical work, namely the existence of diminishing returns to physical capital. We do not find evidence to support the hypothesis of increasing returns resulting from capital externalities. These findings imply that there is a limit to the long-run rate of capital accumulation that can be sustained in the U.S. economy, equal to the rate of increase of the labor force plus the rate of technical improvement. It is, however, possible to bring about a one-time increase in the level of capital intensity and productivity as tong as the United States is willing to accept a lower rate of return to capital.

We find that most of the difference in results between the Denison and Jorgenson studies arises either because the studies do not cover the same universe of output or because one measures net and the other gross output. If the studies are modified to pose the same well-defined question, they give much the same answer. For example, Dale Jorgenson's framework to estimate the contribution of capital to the growth of business output yields results not very different from Edward Denison's, when applied to the same output concept and sector of the economy.

Our reading of the available evidence supports some but not all of the ideas that extend or revise the simple neoclassical model. The postwar pattern of investment and productivity growth in the OECD countries, for example, supports the proposition that some part of technological advance is embodied in capital. There is also evidence for the importance of factor market imperfections in the growth process. Neither finding, however, justifies revising upward the standard model's estimate of capital's contribution to growth in the United States, an economy that is at the technological frontier.

Despite this conclusion, we strongly support efforts to raise the national saving rate by reducing the federal budget deficit. The resulting increase in capital formation would shift upward the future path of GNP growth. Even though the gains from increased capital formation are likely to be small, there is still a case for seeking them. In the long run, a higher rate of saving and investment will lead to a permanently higher level of productivity and to a faster increase in the growth rate as the nation moves from the lower to the higher path. And given the slow growth of productivity in the past 15 years, adding even a few 
tenths of a percent to the growth rate would be a significant improvement.

\section{What Does the Simple Neoclassical Growth Model Show?}

Has the simple neoclassical model failed to track actual economic growth, either within the United States or worldwide? Failure to track history would suggest a need to restructure the theory.

The barebones neoclassical growth model developed by Robert Solow contains the following ingredients. ${ }^{3}$ Output depends upon capital, $K(t)$, labor, $L(t)$, and technology or knowledge, $A(t)$, according to a well-behaved production function with constant returns to scale (to capital and labor).

$$
Q=F(K, L, A) .
$$

Table 1 presents growth data for both the nonfarm business economy and the manufacturing sector of the United States from 1889 through 1987. The concept of capital in the table is restricted to physical capital, excluding owner-occupied housing. Growth in multifactor productivity (an estimate of the rate of change of technology, $A$, as well as any unmeasured sources of growth) is computed in the conventional way from the growth of output minus the weighted average growth rates of capital and labor. This method assumes competitive factor markets.

The data in the table are fairly raw compared with the productivity analyses of Denison and Jorgenson-that is, many growth-inducing factors separately identified by those authors are lumped, in table 1 , into the multifactor productivity residual. We have made one adjustment to the Bureau of Labor Statistics productivity calculations for 194887. The BLS share of capital income includes all indirect business taxes. Not all of these taxes are part of the cost of capital, however, and we, like both Jorgenson and Denison, remove sales and excise taxes from capital income. Table 1 does follow BLS in using gross output and a capital weighting share calculated gross of depreciation.

The adjusted BLS figures show that during 1948-68 the greater part of average labor productivity growth ( 74 percent in nonfarm business

3. Solow (1956). 
Table 1. Average Annual Growth Rates of Output, Labor, Capital, Average Labor Productivity, and Multifactor Productivity, 1889-1987

\begin{tabular}{|c|c|c|c|c|c|}
\hline Period & Output & Labor & Capital & $\begin{array}{c}\text { Average } \\
\text { labor } \\
\text { productivity }\end{array}$ & $\begin{array}{l}\text { Multifactor } \\
\text { productivity }\end{array}$ \\
\hline \multicolumn{6}{|c|}{ Nonfarm business sector } \\
\hline 1889-1909 & 5.11 & 3.01 & 4.81 & 2.10 & 1.63 \\
\hline 1909-1929 & 3.66 & 1.62 & 3.02 & 2.04 & 1.68 \\
\hline $1929-1948$ & 2.77 & 0.85 & 0.72 & 1.92 & 1.94 \\
\hline $1948-1968$ & 3.79 & 1.14 & 3.27 & 2.65 & 1.96 \\
\hline $1968-1973$ & 3.32 & 1.78 & 4.25 & 1.53 & 0.77 \\
\hline $1973-1979$ & 2.49 & 2.03 & 3.72 & 0.48 & -0.03 \\
\hline 1979-1987 & 2.63 & 1.43 & 3.60 & 1.19 & 0.53 \\
\hline \multicolumn{6}{|c|}{ Manufacturing sector } \\
\hline 1889-1909 & 4.32 & 3.03 & 5.64 & 1.28 & 0.92 \\
\hline 1909-1929 & 4.17 & 1.05 & 3.04 & 3.13 & 2.73 \\
\hline 1929-1948 & 3.22 & 1.65 & 0.99 & 1.56 & 1.71 \\
\hline $1948-1968$ & 3.91 & 1.22 & 3.70 & 2.69 & 1.97 \\
\hline $1968-1973$ & 3.49 & 0.33 & 3.28 & 3.15 & 2.31 \\
\hline $1973-1979$ & 1.93 & 0.54 & 3.89 & 1.37 & 0.50 \\
\hline 1979-1987 & 2.32 & -0.96 & 2.02 & 3.29 & 2.48 \\
\hline
\end{tabular}

Sources: 1889-1948 from Kendrick (1961); 1948-1987 from Bureau of Labor Statistics, adjusted by the authors.

a. Estimate of the change of technology or knowledge, $A$.

and 73 percent in manufacturing) was attributable to growth in multifactor productivity. Most of the subsequent slowdown in labor productivity growth came from a slowdown in MFP - indeed, MFP growth turned negative in 1973-79 in the nonfarm business sector.

The data reveal considerable variation in the rates of growth of output, capital, and labor, which allows for a simple test of the hypothesis that the income shares of the factors understate or overstate the contributions of these factors to output growth. Consider a null hypothesis under which the rates of growth of capital, labor, and "true", MFP are stationary random variables and that capital and labor growth are uncorrelated with true MFP. We do not observe true MFP growth, but estimate it using income shares that may differ from the true factor elasticities. If the income shares are less than the true factor elasticities, there will be a positive correlation between measured MFP growth and the factor growth rates. If the income shares are greater than the true elasticities, the correlation will be negative. 
Figure 1. Rate of Growth of Capital and Labor Inputs, Nonfarm Business, Selected Periods, 1889-1989

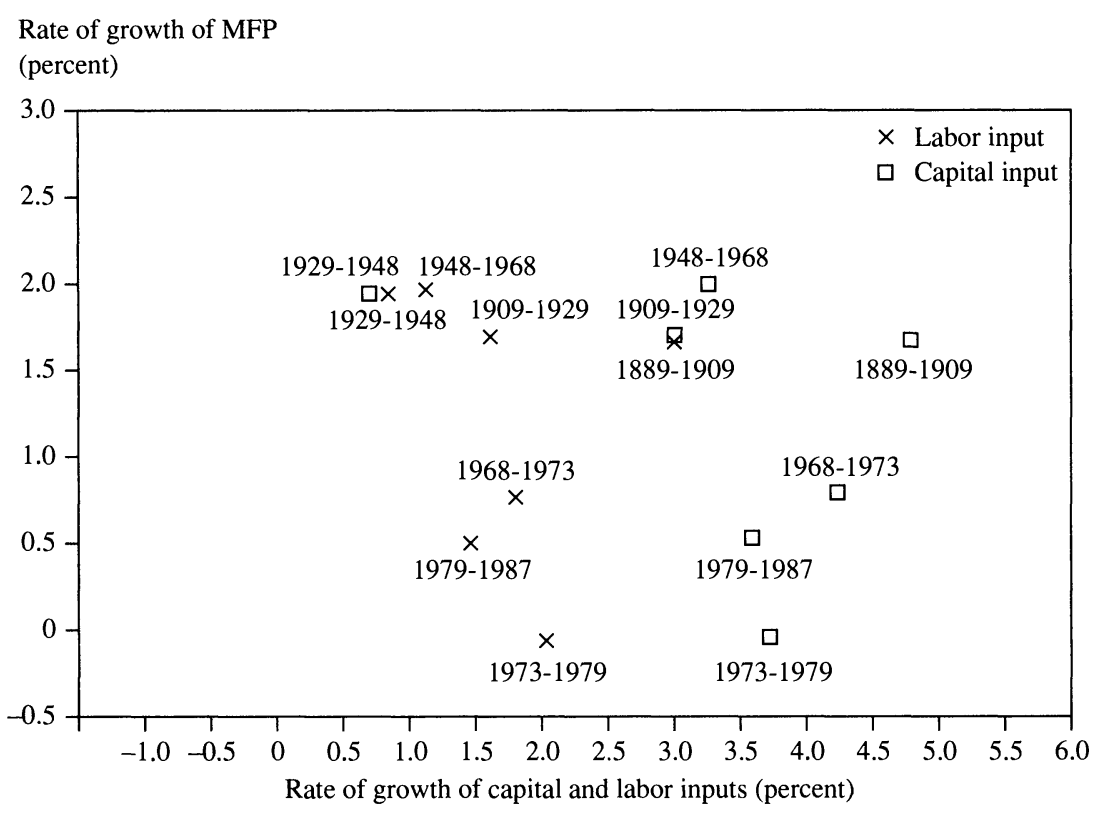

Source: Table 1.

Because the growth rate data are grouped into extended periods to average out cyclical or other short-term variations, there are not enough distinct observations to allow formal statistical tests of the null. We are simply asking: do periods of rapid capital or labor growth correspond to periods of rapid MFP growth?

Figures 1 and 2 are scatter diagrams that reveal negative correlations between the growth rate of both the labor and capital input and that of MFP. These negative relations hold both for nonfarm business and for manufacturing. Certainly these correlations could be due to chance, but they are consistent with the view that income shares may overstate the contributions of labor or capital. In a regression on the nonfarm business data in which both capital and labor growth are included, the negative effect of capital remains, while the labor coefficient turns positive. In the manufacturing sector, both correlations remain negative. These re- 
Figure 2. Rate of Growth of Capital and Labor Inputs, Manufacturing, Selected Periods, 1889-1989

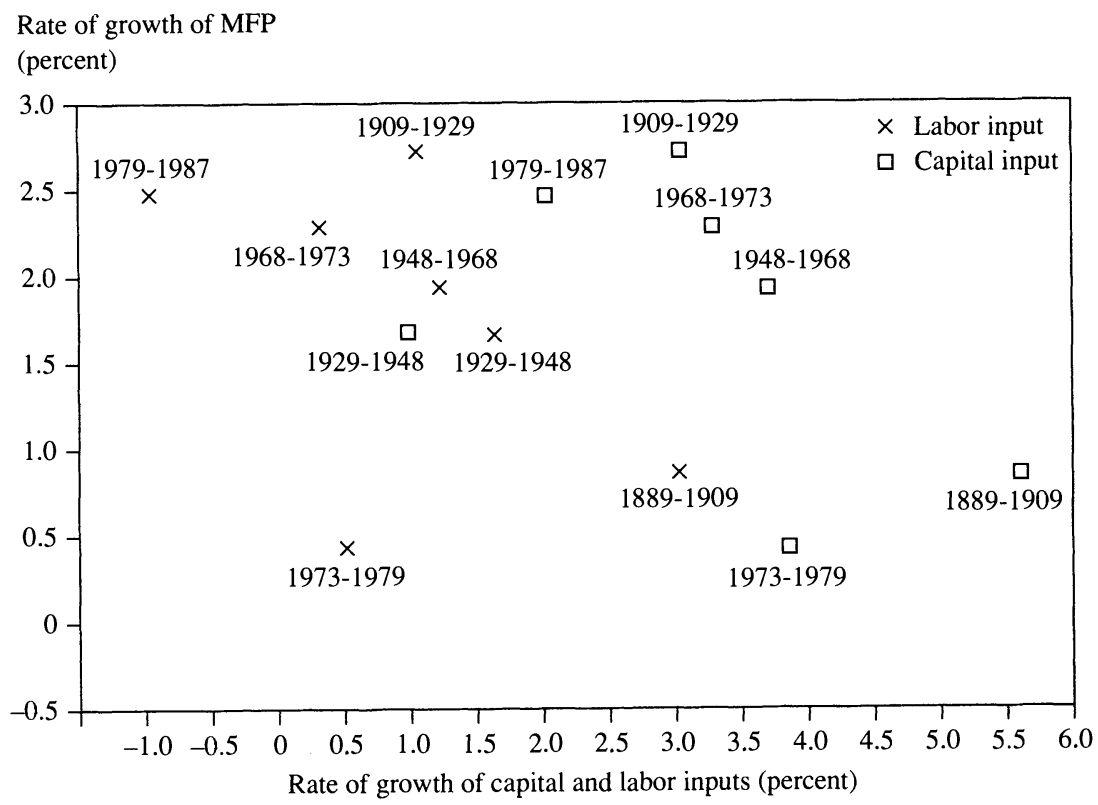

Source: Table 1.

sults do not provide a very promising start for any effort to show increasing returns.

Paul Romer has tried to explain the negative correlation between MFP and labor by arguing that increases in labor input will lower the real wage and then discourage innovation. ${ }^{4} \mathrm{We}$ do not know of microeconomic evidence to support this idea, but it is consistent with the aggregate data for manufacturing. For nonfarm business the negative correlation between MFP and labor is too fragile to argue that it supports his hypothesis.

Neoclassical theory itself suggests that the rate of MFP growth and the rate of growth of capital are positively correlated. The rate of growth of the capital-labor ratio consistent with a nondeclining return to capital is equal to the rate of MFP growth divided by the labor share of income.

4. Romer (1988, 1990). 
Even off the steady state, we would expect changes in the rate of technological advance to induce changes in the rate of capital growth. Rather than a null hypothesis that capital growth and MFP growth are uncorrelated, a more appropriate null is that they have a positive correlation. But the actual data cast doubt on this stronger null. Periods to note include 1929-48, when there was little capital accumulation and solid MFP growth, and 1968-79, when there was solid capital accumulation and little MFP growth in the nonfarm business sector.

\section{The Growth Model and Steady-State Growth}

To generate a framework that allows steady-state growth, the neoclassical growth model adds to the production function the assumption that technology is labor-augmenting. It is often assumed further that gross saving is a constant fraction, $s$, of output; that the rate of growth of the labor force is a constant, $n$; that the rate of growth of technology is a constant, $g$; and that the proportional rate of depreciation is a constant, $\delta$. These assumptions lead to the familiar growth equation:

$$
d k^{*} / d t=s f\left(k^{*}\right)-(n+g+\delta) k^{*} .
$$

In this expression, $k^{*}$ is the ratio of capital to augmented labor, $K /(A L)$, and $f$ is the intensive production function, equal to output per unit of augmented labor, $Q /(A L)$.

The model reaches four descriptive conclusions about economic growth for economies with steady rates of increase of labor input and technology. First, they will converge toward paths of steady-state growth. Second, once they reach a steady-state point, there will be a constant ratio of capital to output and a constant marginal rate of profit. Third, wages and average labor productivity will grow at the same rate, $g$, as the rate of technological change. And finally, output will grow at a constant rate, $n+g$.

An economy that starts with a ratio of capital to augmented labor below the steady-state level will have a rate of profit above the longrun equilibrium value and will experience a declining marginal product of capital, rates of wage and labor productivity growth that exceed the rate of labor-augmenting technological change, and a rising capitaloutput ratio. In general, if we observe an economy that is not in steady- 
Table 2. Growth Rates of Labor-Augmenting Technical Change (LATC) and Augmented Labor, Selected Periods, 1909-87

Percent a year

\begin{tabular}{cccccc}
\hline & \multicolumn{2}{c}{ Nonfarm business } & & \multicolumn{2}{c}{ Manufacturing } \\
\cline { 2 - 3 } \cline { 5 - 6 } Period & LATC & $\begin{array}{c}\text { Augmented } \\
\text { labor }\end{array}$ & & LATC & $\begin{array}{c}\text { Augmented } \\
\text { labor }\end{array}$ \\
\hline $1909-29$ & 2.25 & 3.87 & n.a. & n.a. \\
$1929-48$ & 2.47 & 3.32 & & n.a. & n.a. \\
$1948-68$ & 2.87 & 4.01 & & 2.79 & 4.01 \\
$1968-73$ & 1.11 & 2.89 & & 3.22 & 3.55 \\
$1973-79$ & -0.04 & 1.99 & & 0.68 & 1.22 \\
$1979-87$ & 0.77 & 2.20 & & 3.39 & 2.43 \\
\hline
\end{tabular}

Source: Authors' calculations.

n.a.: Not available.

state growth $\left(d k^{*} / d t\right.$ is nonzero), the behavior of the marginal product of capital (the gross rate of profit) should provide direct evidence of the extent of diminishing returns to aggregate physical capital.

Table 2 includes data on the rate of labor-augmenting technical change, calculated as the rate of MFP growth divided by the labor share of income, and on the rate of growth of augmented labor (equal to the sum of the rates of growth of actual labor input and the rate of growth of technical change). Table 3 shows data on the levels of the ratio of capital to augmented labor $\left(k^{*}\right)$, the ratio of capital to output, the labor share of income, and the gross return to capital. This last number is calculated from our adjusted BLS data as the ratio of capital income to the capital input.

The data in tables 1, 2, and 3 do not support the view that the U.S. economy has converged to a single steady-state growth path. ${ }^{5}$ But in interpreting the implication of the data in the tables we must take account of the fact that the rate of growth of augmented labor has not been constant. The saving propensity may also have varied. But with those caveats in mind, we can see how the simple growth model performs over the postwar period before and after the growth slowdown, modeled as a change in the rate of labor-augmenting technical change.

5. The emphasis on steady-state growth in the neoclassical growth model was largely in response to the Harrod-Domar model, which implied that stable long-term growth was difficult or impossible to achieve. Solow clairned that flexibility in the capital-output ratio would allow, in Harrod's terminology, the warranted rate of growth to equal the natural rate of growth. 
Table 3. Level of the Ratio of Capital to Augmented Labor, Ratio of Capital to Output, Labor Share of Income, and Gross Profit Rate, Nonfarm Business Sector, Selected Years, 1948-87

\begin{tabular}{ccccc}
\hline Year & $\begin{array}{c}\text { Capital to } \\
\text { augmented labor }\end{array}$ & $\begin{array}{c}\text { Capital to } \\
\text { output }\end{array}$ & $\begin{array}{c}\text { Labor } \\
\text { share }\end{array}$ & $\begin{array}{c}\text { Profit } \\
\text { rate }\end{array}$ \\
\hline 1948 & 1.00 & 2.33 & 68.4 & 13.59 \\
1968 & 0.86 & 2.10 & 68.0 & 15.25 \\
1973 & 0.92 & 2.20 & 70.2 & 13.55 \\
1979 & 1.02 & 2.36 & 69.8 & 12.78 \\
1987 & 1.13 & 2.56 & 68.6 & 12.29 \\
\hline
\end{tabular}

Source: Authors' calculations.

\section{The Growth Model and the Slowdown}

Figure 3 illustrates what happens when the rate of labor-augmenting technological change drops from $g_{1}$ to $g_{2}$. We have drawn the figure showing an economy that was initially at a position of steady-state growth (point $A$ ). Following the decline in the rate of technological change, the economy will make a gradual transition to a new steadystate growth path, reached at point $B$ in the figure. The decline in $g$ triggers an immediate decrease in the rate of growth of output and labor productivity. The rate of growth of the capital stock, however, does not immediately decrease. Over time, the result is a rise in the ratio of capital to augmented labor, a decline in the rate of profit, and then, gradually, a decline in the rate of growth of the capital stock itself. Once the new steady state is reached, capital and labor are again growing at the same rate.

One implication of this model is that the decline in the rate of growth in labor productivity gradually worsens as the economy makes the transition from point $A$ to point $B$. Even with a constant propensity to save, the rate of capital accumulation will decline over time.

Technological change has a double benefit in the simple growth model. First, it increases the rate of growth of output directly; second, it increases the rate of capital accumulation consistent with a constant rate of profit. Both then contribute to the growth in average labor productivity. The first benefit is lost right away when the rate of technological change declines. The second benefit is lost gradually as the economy moves around the intensive production function. This idea is 
Figure 3. Effect of a Decline in Rate of Labor-Augmenting Technical Change

Ratio of output to

augmented labor

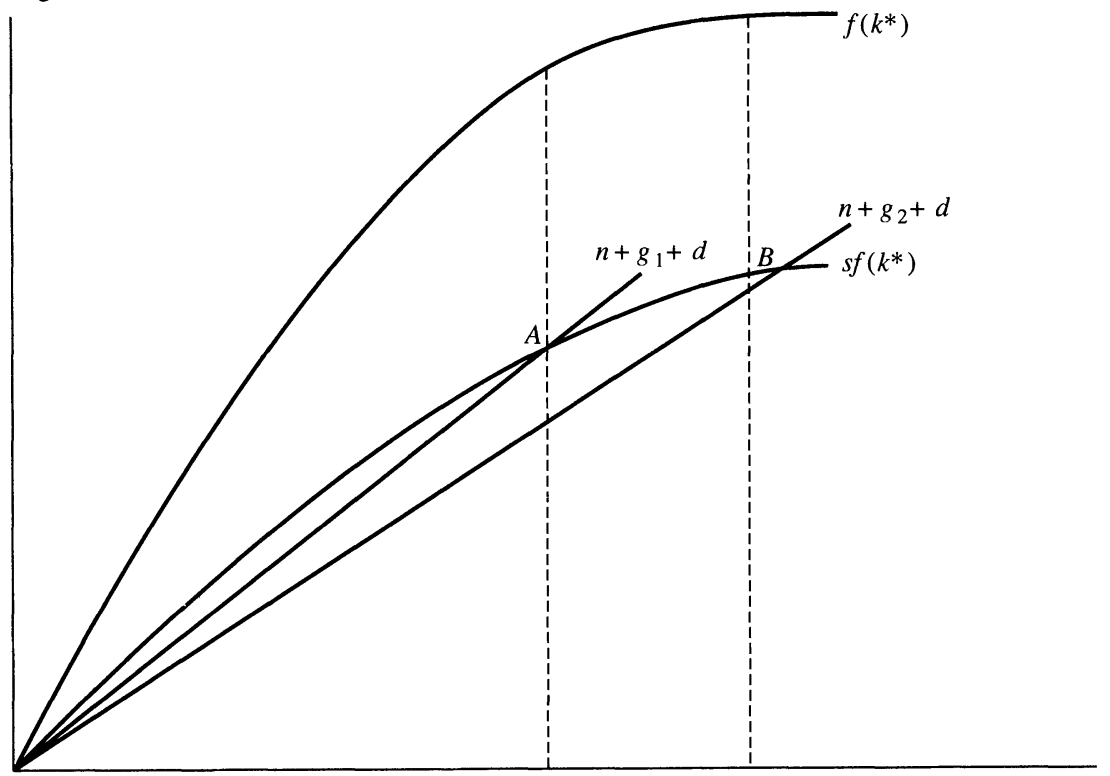

Ratio of capital to augmented labor

Source: Table 1.

hardly new,${ }^{6}$ but it can be forgotten in a conventional analysis that separates growth of multifactor productivity and the growth of the factor inputs. Such an analysis might conclude, somewhat misleadingly, that part of the slowdown in output growth was the result of the decline in MFP growth and part was the result of a slowing of the growth of the capital input. The conclusion is technically correct, but misses the point that the decline in the rate of capital formation might itself have been a response to the decline in the rate of technical change. ${ }^{7}$

How does the model's description of the effects of a slowdown compare with the data? In the nonfarm business sector of the economy,

6. See, for example, Hulten (1979).

7. Of course, the fall in capital formation might also have been exogenous-a response to lower domestic saving not offset by capital inflow from abroad. 
the rate of growth of augmented labor exceeded the rate of capital growth from 1948 through 1968. The economy was underinvesting at that time, relative to the steady-state growth path, as the economy moved around the intensive production function to the left. In terms of figure 3 , the economy was actually to the right of point $A$, moving slowly back toward $A$. After 1968 , the situation was reversed. The rate of capital accumulation exceeded the rate of growth of augmented labor, and the economy was moving around the intensive production function to the right. The economy was making the transition to the new steady state at $B$.

These changes should have caused both the capital-output ratio and the rate of profit to rise before 1968 and fall thereafter. And for nonfarm business that is exactly what they did. In terms of the current debate about the productivity of capital, the data indicate that capital accumulation in excess of the natural growth rate since 1968 has driven down the marginal product of capital-that is, there are diminishing returns to physical capital. ${ }^{8}$

One implication of our analysis is that using steady-state results is not a good idea, either as a basis for prediction or as a guide to policy. For example, the current rate of capital formation implies a falling marginal product of capital. And, while obviously this cannot go on forever, it could persist for a long time without a really large drop in the return to capital, given the magnitude of the relevant coefficients. On the assumption of a unitary elasticity of capital-labor substitution, conventional growth theory predicts that the return to capital will decline each year by a percentage equal to the excess of the growth in the capital-labor ratio over the labor-augmenting rate of technical change. For the period 1968-79 the theory predicts that the return to capital would have fallen from 15.3 percent to 13.1 percent. In fact, it fell to 12.3 percent.

The labor share of income in the nonfarm business sector has remained rather stable at 68-70 percent throughout the postwar period, according to our adjusted BLS data (the unadjusted share is also stable in the range of 64-66 percent). This suggests that the elasticity of substitution is not too far from unity. It also means that the assumption

8. In terms of the old Cambridge-Cambridge debate, Solow's contention that flexibility in the capital-output ratio could avoid knife-edge growth instability is strongly supported. 
Table 4. Estimated Elasticities of Capital-Labor Substitution, Nonfarm Business Sector, Selected Periods, 1948-87

\begin{tabular}{cc}
\hline Period & Elasticity \\
\hline $1948-68$ & 0.89 \\
$1968-73$ & 0.40 \\
$1973-79$ & 1.20 \\
$1979-87$ & 1.91 \\
$1948-87$ & 0.86 \\
\hline
\end{tabular}

Source: Authors' calculations.

of labor-augmenting, as opposed to Hick's neutral or capital-augmenting technical change, is fairly innocuous. If we were to assume an elasticity of substitution of unity, the model predicts that the rate of profit moves in simple inverse proportion to the capital-output ratio.

In practice, the income shares have not been perfectly constant, but for small changes (or more generally if the production function is CES) one can relate the profit rate to the elasticity of substitution as follows:

$$
d \ln \pi=\frac{S_{l}\left(d \ln k^{*}\right),}{\sigma}
$$

where $\pi$ is the profit rate, $S_{l}$ is the labor share, and $\sigma$ is the elasticity of substitution.

Table 4 gives the estimated elasticity of capital-labor substitution for the periods after 1948. If the production function were perfectly stable, then the elasticity should be the same in all periods, and it is not. The obvious outliers are 1968-73 and 1979-87. These probably occurred because of the upward push on the wage share that took place in 196873 , the period that William Nordhaus calls one of "worldwide wage explosion," followed by the decrease in the wage share during 197987 , at a time of declining union strength and deregulation. ${ }^{9}$ This discrepancy between the model and the results in table 4 suggests, therefore, that the assumption of perfectly competitive factor markets may be incorrect.

In contrast to the analysis for the nonfarm sector, the analysis for manufacturing does not support the model. In particular, augmented labor grew more rapidly than capital during both 1968-73 and 197987 , and yet the profit rate declined in both periods, just as it did for

9. Nordhaus (1972). 
the nonfarm business sector as a whole, where capital was growing more rapidly than augmented labor. There are several possible explanations. One may be that there are not diminishing returns to capital in the manufacturing sector. Another may be the difficulty of allocating profit income to manufacturing when many firms operate both within and outside manufacturing. (The statistical agencies are tempted to apply the economywide profit rate to manufacturing.) A third, and possibly the most important, may be that the share of income going to workers in manufacturing rose more sharply than it did for workers generally from 1968 to 1973 because of the fact that unionized workers are concentrated in the manufacturing sector.

\section{The Growth Model, International Convergence, and Capital Flows}

Paul Romer and Robert Lucas have recently suggested that the pattern of international growth and capital flows is inconsistent with the simple growth model. ${ }^{10}$ If they are correct, the estimates of capital's contribution to growth may have to be revised upward.

Romer and Lucas base their argument on two main points. First, if pure scientific knowledge is a public good available to all countries and there are diminishing returns to capital formation, then, according to the simple growth model, all countries in the world should be converging to steady-state growth paths with the same rate of growth. But, in fact, growth is not slowing in the rich countries, and the poor countries are not growing faster than the rich. The gap between the rich and poor countries of the world is not narrowing.

Second, poorer countries should have higher marginal products of capital than richer countries, and so capital should flow from rich to poor. In fact, they say, international capital flows are not from the capital-rich countries to the capital-poor countries.

They conclude that the evidence runs counter to the assumptions of the simple neoclassical model and suggests that capital is not subject to diminishing returns. How should we balance this international evi-

10. Romer (1986); and Lucas (1988). 
dence against the countervailing evidence from growth within the United States?

The facts that they give about the convergence of growth rates are subject to dispute. William Baumol, Sue Anne Batey Blackman, and Edward Wolff find strong evidence of convergence among a large group of countries. ${ }^{11}$ The greater part of the world's GNP (excluding the Eastern bloc) is now produced within countries whose productivity levels cluster fairly closely together. Romer and Lucas reject the Baumol, Blackman, and Wolff evidence on the grounds that it supports convergence only if most countries of the world are omitted from the sample. It is true that on an unweighted basis-that is, by a simple count-most countries have not converged. But it is also true that virtually all nonsocialist countries that were already "successful" 40 years ago have converged. ${ }^{12}$

There are several possible explanations of the convergence pattern. One that has been around in the literature of economic development for many years is that the production function exhibits increasing returns at low levels of income but not at high levels. In this case, countries can get stuck at low income levels, and need a big push to achieve development. If this explanation is correct, then Lucas and Romer are correct for some countries, but Solow's neoclassical growth model is correct for the United States and other developed countries.

An alternative argument is that the components of growth stressed in the conventional neoclassical theory-technical advances, capital accumulation, and so forth-are necessary but not sufficient conditions for growth, and that the "unsuccessful" countries lack some essential growth element. Thus, economic growth may have been slow in many developing countries because economic policies have been bad or because market incentives have not been allowed to operate well. Many developing countries also face adverse initial conditions, including high population growth rates.

One can make an argument about capital flows similar to the one we have just made about convergence. In Europe and the United States in the 1950s, capital flowed from the capital-rich United States to a Europe

11. Baumol, Blackman, and Wolff (1989).

12. Successful here means having per capita incomes that were already within range of the U.S. level. 
that had lost much of its capital. Capital certainly would have flowed into Japan also if that flow had not been restricted. More recently, capital has been flowing into the United States in response to the low U.S. national saving rate and declining rates of profit in Europe and Japan. These countries are now probably more capital-intensive than the United States. ${ }^{13}$ Capital also flowed into the United States in the nineteenth century at a time when opportunities were greater here than in Europe.

Capital may not flow to developing countries because they are stuck in the range where the marginal product of capital is low for small increases in capital, even though a big increase in capital would move them into the takeoff stage of development. Other reasons why capital may not flow into some countries include the adverse policy environment or the lack of certain complementary factors of production available in developed countries, but not transferable to low-income countriesskilled and experienced labor and social overhead capital, for example. Technological knowledge may also be immobile if companies have trade secrets.

We conclude that the convergence of productivity levels among the economies of the United States, Europe, and Japan provides support for applying the neoclassical growth model to countries such as these. For many reasons, we would be reluctant to apply the model to developing countries. We also suggest that there are more plausible explanations of the international pattern of capital flows than externalities from capital.

We would stress, however, that we are restricting our discussion in this paper to physical capital. Lucas has emphasized externalities from human capital, and Romer has recently stressed the externalities from technological capital in contrast to his earlier emphasis on externalities from physical capital. We agree with Romer and the large literature that finds substantial spillovers from R\&D. ${ }^{14}$

13. It is hard to make precise international comparisons of capital intensity because the measurement of the absolute level (as opposed to the rate of growth) of the capital stock is not always consistent in methodology among countries.

14. In an earlier version of this paper, we included data on R\&D capital and estimated the extent to which the externalities from $R \& D$ could result in increasing returns to scale. We found that returns to scale of about 1.07 were consistent with (generous) estimates of the excess social rate of return from $R \& D$. 


\section{Implications of the Neoclassical Model for Future Growth}

The simple model has done well enough in explaining past growth that we think it worth taking a look at what it implies about American growth prospects. The rate of MFP growth has been so variable over the postwar period that it seems rash to make particular predictions of this growth rate in the future. Baumol, Blackman, and Wolff have argued that the growth slowdown is not all that unusual historically and that a pickup can be expected in the future. ${ }^{15}$ Let us hope they are correct, because without such a pickup, the prospects are very gloomy. The rate of labor productivity growth can exceed the growth of laboraugmenting technical change only if the capital stock grows faster than output. But that depresses the profit rate, as has been the case for more than two decades. The latest period, since 1979, is no exception. Average labor productivity has been growing 1.2 percent a year; the rate of labor-augmenting technical change has been about 0.8 (an MFP of 0.53 divided by a labor share of 0.69 ); and the difference has been made possible by a growth of the capital stock significantly in excess of the rate of growth in output (see table 3). Assume that the rate of labor-augmenting technical change remains at its current 0.8 percent, and the labor force grows at its currently projected rate of 1.4 percent a year. Then the natural rate of growth in the economy (the rate at which the capital-output ratio and the profit rate are constant) will be about 2.1 percent a year-less than the current rate of growth of nonfarm business sector output and the current rate of growth of the capital stock. In terms of figure 3 , the economy still has a long way to go to complete the transition to point $B$. In the absence of any increase in MFP growth, the nonfarm business sector of the U.S. economy can be expected over the medium-term future to suffer from some combination of a declining rate of growth of output and a continued decline in its rate of profit.

\section{Adjusting the Factor Inputs: Denison and Jorgenson}

The original Abramovitz-Solow growth analysis, which first credited physical capital with such a small contribution to labor productivity

15. Baumol, Blackman, and Wolff (1989). 
Table 5. Alternative Estimates of Capital's Contribution to Economic Growth, Total Economy, 1948-79

\begin{tabular}{lccc}
\hline & $\begin{array}{c}\text { Growth } \\
\text { rate of } \\
\text { labor } \\
\text { productivity }\end{array}$ & $\begin{array}{c}\text { Contribution of capital } \\
\text { accumulation }\end{array}$ \\
\cline { 3 - 4 } Estimate & 2.39 & $\begin{array}{c}\text { Percentage } \\
\text { points }\end{array}$ & $\begin{array}{c}\text { Percentage } \\
\text { of } \\
\text { total growth }\end{array}$ \\
\hline $\begin{array}{l}\text { Denison } \\
\text { Jorgenson, Gollop, } \\
\text { and Fraumeni }\end{array}$ & 2.35 & 0.38 & 0.16 \\
\hline
\end{tabular}

a. Denison (1985). The output measure is Denison's actual national income. For comparability with Jorgenson, we adjusted Denison's results from a measure of output per person employed to output per hour worked. Capital includes land and excludes international assets.

b. Jorgenson, Gollop, and Fraumeni (1987). The estimates shown above were calculated from data in tables 8-1, 8-2, 9-2, and 9-3. The estimates cover the output of total economy, including the services of consumer durables.

growth, assigned the overwhelming part of productivity growth to an unexplained residual. A growth model that assigns most of what it is supposed to explain to a residual is obviously not a satisfactory or complete model. And in the years since the early results appeared, Dale Jorgenson and Edward Denison have been the leaders in attempting to reduce the size of the unexplained residual and provide a more satisfactory explanation for growth. Both have stressed the importance of careful measurement of the factor inputs and of the need to introduce additional explanatory variables, most notably human capital. This timeconsuming and important work has contributed greatly to our understanding of economic growth.

Although in many ways their efforts have been made in parallel, the two researchers have used different strategies in several respects and have come to what look like very different conclusions about the importance of capital to growth. Denison does explain part of the unexplained residual, but does not increase the size of the capital contribution. His findings simply reinforce the early finding that capital's contribution is small. Jorgenson reduces the size of the unexplained residual, in large part by assigning a much bigger role to capital.

Table 5, drawing on the latest estimates by Denison on the one hand and the recent book by Jorgenson, Frank Gollop, and Barbara Fraumeni, on the other, highlights the differences. ${ }^{16}$ Denison finds that the rise in the capital-labor ratio accounted for only one-sixth of the growth in

16. Denison (1985); Jorgenson, Gollop, and Fraumeni (1987). 
labor productivity during the first three decades after World War II (almost precisely the same fraction as emerged from the original Solow study for the preceding four decades, 1909-49). Jorgenson, Gollop, and Fraumeni, on the other hand, attribute half of labor productivity growth to capital accumulation. Clearly, in assessing both growth theory and investment policies we need to understand how these differences arise.

An obvious difference in the methodologies of the two studies is that Denison does not see the standard neoclassical production function as being at the heart of his analysis. He has looked for ways to take account of the impact of such tricky factors as crime and pollution on productivity. He also argues that the contribution of capital to growth should exclude any capital-embodied technology and should net out depreciation-as did Solow's original analysis. He is accounting for the sources of growth with an eye on the contribution of growth to consumption in the long run.

Jorgenson has made the neoclassical production function the basis of his productivity analysis. In particular, he has emphasized the need for rigorous aggregation procedures, which he accomplishes by assuming a translog production function and Divisia input indexes. In this vein, he and Griliches, and later he, Gollop, and Fraumeni, emphasize the construction of an aggregate series of capital inputs that, as much as possible, weights different types and vintages of capital by their respective marginal products. ${ }^{17}$ In practice, this involves three different sets of measurement problems. The first is estimating the rate at which the various components of the capital stock lose efficiency with the passage of time. The second is capturing, wherever possible, the effects of technological improvements embodied in capital as increases in the effective stock of capital (through hedonic price deflators). And the third is weighting sectoral growth rates of the capital stock with sectoral rental price measures (translog input indexes) to capture the effect of shifts in the composition of the aggregate capital stock among types of capital with different returns (that is, with different marginal products). They find that the translog indexes of capital inputs reveal a large shift in the composition of capital during 1948-79 toward components with relatively high rental rates (and presumably, therefore, high marginal 
products). The authors also emphasize the difference between themselves and Denison with respect to the measurement of the decline in capital efficiency with age.

In the Jorgenson, Gollop, and Fraumeni analysis, the aggregate flow of capital services grew at a 4.1 percent average annual rate, of which one quarter came not from an increase in the aggregate capital stock but from a shift in its composition to types of capital with higher (gross) marginal products.

This approach contrasts with Denison, who uses a capital stock measure that gives great weight to a "one hoss shay" assumption about efficiency decline. ${ }^{18}$ As noted earlier, Denison strongly opposes incorporating technological progress in the measure of capital inputs, arguing that it should be allowed to show up in the measure of multifactor productivity growth. And while he does, in effect, distinguish and separately weight three components of the capital stock (land, residential structures, and business capital), he does not attempt the much more detailed disaggregation and weighting scheme that has been developed over the years by Jorgenson with various coauthors.

These differences in approach between Denison and Jorgenson have been the source of discussion and disagreement and are the ones that we expected would explain the differences in the empirical findings. They may indeed be important for some questions, but we find that they do not in practice seem to explain much of the wide discrepancy between the two sets of empirical results in their estimates of the importance of capital. Most of the divergence comes simply from the fact that the two studies cover different segments of the economy. When they are adjusted to cover the same "domain" of output, the Jorgenson estimates of the contribution of capital turn out to be only moderately higher than those of Denison.

Denison analyzes the growth of net output; Jorgenson, Gollop, and Fraumeni analyze gross output. Denison gives estimates both for the total economy and for the nonresidential business sector. The aggregate measures that the Jorgenson team presents cover the entire economy, approximately as defined by the official U.S. national income account statistics, plus the imputed gross flow of services from the stock of

18. The legendary one hoss shay kept running well until the moment it finally collapsed of old age. 
durables owned by consumers and nonprofit institutions. Jorgenson and his colleagues also include government production.

To show the effects of the differences in treatment, we have adjusted both sets of estimates to cover net output in the nonresidential business sector of the economy. That adjustment principally involved converting the Jorgenson output measures and capital share weights from a gross to a net basis and subtracting from the Jorgenson aggregate inputs and outputs those relating to the services of consumer durables, dwellings (both tenant- and owner-occupied), and nonprofit institutions. But we also converted Denison's measures of labor productivity from an output per person to output per hour to provide comparability with Jorgenson and, again for comparability, combined Denison's tangible capital and land inputs into one "capital" input, adjusting his property compensation weights accordingly. We could have expanded Denison's universe to match that of Jorgenson, Gollop, and Fraumeni rather than contracting theirs to meet Denison's. But the results, in terms of narrowing the differences between the two sets of studies, would have been virtually the same.

The Jorgenson-Gollop-Fraumeni estimates of the postwar capital contribution are higher than Denison's mainly because their gross output measure includes, while Denison's net output in the nonresidential business sector excludes, a substantial amount of nonbusiness output in which capital contributes almost 100 percent of the growth-the services of consumer durables and of residential structures plus economywide capital consumption.

Let's start with capital consumption. Everything else being equal, an analysis of the sources of the growth in gross output will, simply from the arithmetic of growth accounting, assign a larger contribution to the growth of capital than will an analysis of net output. Since historically net and gross output have grown at quite similar rates it would not seem to make much practical difference which one was used in the analysis. But here intuition is wrong. Think of gross national product as being composed of two components: net national product and capital consumption. That part of the growth in GNP represented by the growth in capital consumption is, by definition, 100 percent contributed by capital input. The contribution of capital to the other component is, of course, much smaller. When the growth of GNP is being analyzed, the capital contribution will be a weighted average of 
its contribution to the first component ( 100 percent) and its much smaller contribution to the second component. When net output is being analyzed, only the capital contribution to the second component is included. Operationally this is reflected in the fact that the weight given to the capital input in studies of the growth of gross output is equal to the gross property income share, while Denison argues that the appropriate weight in analyses of net output is the net property share. ${ }^{19}$

Neither approach is necessarily right or wrong. From the perspective of tracking an aggregate production function-the Jorgenson approach - gross output and the gross share make sense. Denison, on the other hand, wants to adjust for the fact that the ultimate value of capital comes from its ability to produce net output. The fact that increases in capital add to gross output because they increase depreciation is not a plus. Denison does not want to count this as part of capital's contribution to growth.

The next important source of the difference in results stems from the inclusion of the services of residential structures, consumer durables, and nonprofit institutions in the Jorgenson team's analysis, outputs that are excluded from the Denison measure of output in the nonresidential business sector. These exceedingly capital-intensive sectors account for 21 percent of the Jorgenson output measure in 1979, and the capital share of income originating is 94 percent. The capital contribution to the growth of the Jorgenson-Gollop-Fraumeni aggregate output measure is thus a weighted average of a modest capital contribution in the business nonresidential sectors of the economy and a 94 percent contribution in the remaining sectors that, as noted, account for over 20 percent of output.

Partially offsetting this feature of the Jorgenson-Gollop-Fraumeni analysis is their inclusion, and Denison's exclusion, of the output of the general government sector where the capital contribution, by definition, is zero. The results of these adjustments, expressed in terms

19. This choice of weights, gross as against net property compensation, is quite independent of the selection of the appropriate measure of capital stock to represent capital inputs. Thus Denison, who analyzes net output, constructs an index of capital input by weighting the gross stock 0.75 and the net stock 0.25 , while Jorgenson, Gollop, and Fraumeni, who analyze gross output, use a measure of capital inputs that is different from either the gross or the net capital stock. 
Table 6. Adjusted Comparison of Alternative Estimates of Capital's Contribution to Growth, 1948-79

\begin{tabular}{|c|c|c|c|c|c|}
\hline \multirow[b]{2}{*}{ Category and estimate } & \multirow{2}{*}{$\begin{array}{c}\text { Output } \\
\text { per hour } \\
\text { worked }\end{array}$} & \multirow{2}{*}{$\begin{array}{c}\text { Capital- } \\
\text { labor } \\
\text { ratio }\end{array}$} & \multirow[b]{2}{*}{$\begin{array}{l}\text { Capital } \\
\text { share }\end{array}$} & \multicolumn{2}{|c|}{$\begin{array}{c}\text { Capital contribution } \\
\text { to growth } \\
\end{array}$} \\
\hline & & & & $\begin{array}{l}\text { Percentage } \\
\text { points }\end{array}$ & $\begin{array}{l}\text { Percent } \\
\text { of total }\end{array}$ \\
\hline \multicolumn{6}{|l|}{$\begin{array}{l}\text { Gross output } \\
\quad \text { total economy }\end{array}$} \\
\hline $\begin{array}{l}\text { Jorgenson, Gollop, and } \\
\text { Fraumeni }\end{array}$ & 2.35 & 2.99 & 0.39 & 1.15 & 0.49 \\
\hline \multicolumn{6}{|c|}{$\begin{array}{l}\text { Net output, } \\
\quad \text { nonresidential business }\end{array}$} \\
\hline $\begin{array}{l}\text { Denison } \\
\text { Jorgenson, Gollop, and }\end{array}$ & 2.55 & 2.17 & 0.19 & 0.42 & 0.16 \\
\hline Fraumeni & 2.09 & 2.56 & 0.20 & 0.52 & 0.25 \\
\hline \multicolumn{6}{|l|}{ Excluded sectors ${ }^{\mathrm{a}}$} \\
\hline $\begin{array}{l}\text { Jorgenson, Gollop, and } \\
\text { Fraumeni }\end{array}$ & 2.01 & 2.24 & 0.70 & 1.56 & 0.78 \\
\hline
\end{tabular}

of capital's contribution to the growth in output per hour worked, are shown in table 6 with the backup data given in table $7 .^{20}$

In the unadjusted Jorgenson estimates for the total economy, the rise of the capital-labor ratio contributes fully half of the growth in labor productivity in the years between 1948 and 1979. After the two analyses are standardized to cover roughly the same output definition, their estimates of the contribution of capital to the growth of labor productivity are much closer to each other. According to Denison, capital formation in the nonresidential business sector accounted for an average of 0.42 percent a year to output growth; according to Jorgenson, Gollop, and Fraumeni, the capital contribution for that sector is only marginally higher, 0.53 percent.

20. The data needed to exclude the private household and institutional sectors are available from the tables in Jorgenson, Gollop, and Fraumeni; we estimated the needed data on the output, property income, and capital stocks involved in tenant-occupied housing from the Bureau of Economic Analysis national income accounts tables. We used BEA estimates of capital consumption allowances for the relevant sector. 
Table 7. Basic Data for Comparing Alternative Estimates of Capital's Contribution to Growth, 1948-79

Average annual growth rate

\begin{tabular}{lccc}
\hline $\begin{array}{l}\text { Category and estimate } \\
\text { Gross output, total economy }\end{array}$ & Output & $\begin{array}{c}\text { Hours } \\
\text { worked }\end{array}$ & $\begin{array}{c}\text { Capital } \\
\text { input }\end{array}$ \\
$\begin{array}{l}\text { Jorgenson, Gollop, and } \\
\quad \text { Fraumeni }\end{array}$ & 3.48 & 1.13 & \\
$\begin{array}{l}\text { Net output, nonresidential business } \\
\text { Denison }\end{array}$ & 3.37 & & 4.12 \\
$\begin{array}{l}\text { Jorgenson, Gollop, and } \\
\quad \text { Fraumeni }\end{array}$ & 3.03 & 0.82 & 2.99 \\
\end{tabular}

Excluded sectors ${ }^{\mathrm{a}}$

Jorgenson, Gollop, and

Fraumeni

4.44

2.43

4.67

Sources: see table 6 .

a. See table 6 , note a.

As shown in table 7, the Jorgenson estimate of the growth of net output in the nonresidential business sector between 1948 and 1979 is substantially less than that of Denison. While this difference does not affect their measures of capital's contribution, it is puzzling, since both estimates refer to the same sector of the economy. The appendix examines this discrepancy and suggests it may have arisen from the sectoral deflation techniques employed by Jorgenson and his colleagues, which apparently yield an overall implicit deflator that grew faster than those in the Department of Commerce's national income and product accounts, which are the basis of the Denison estimates.

\section{Remaining Difference in the Estimate of Capital Contribution}

The modest remaining difference in the assessment of capital's contribution to growth stems almost entirely from the fact that the Jorgenson measure of aggregate capital input per worker grows somewhat more rapidly than does Denison's. This is the component of the disparity that arises because the Jorgenson translog index of capital inputs reflects a shift of capital composition to types of capital with relatively high gross rental rates. But this disparity in the magnitude of the capital contri- 
bution would be reduced if we had been able to reweight the translog indexes of capital inputs with weights based on net rather than gross rates of return. Most of the growth of the Jorgenson-Gollop-Fraumeni aggregate index of capital input that is attributed to changes in capital quality occurred because of a shift of the composition of the capital stock among asset classes (such as producers' durable equipment, nonresidential construction, inventories, and so on) that have quite different depreciation rates and therefore quite different gross rates of return. ${ }^{21}$

During the postwar period, the share of total investment represented by producers' durable equipment, with its relatively high depreciation rates, rose sharply at the expense of other types of investment with much smaller depreciation rates (or in the case of inventory investment, a zero rate). ${ }^{22}$ To illustrate the effect of this shift, consider a production function in which gross output, $G Q$, is produced by two kinds of capital, $K_{1}$ and $K_{2}$, and other factors, $X$ :

$$
G Q=F\left(K_{1}, K_{2}, X\right) .
$$

Type 1 capital has a larger rate of depreciation than type 2 capital:

$$
\delta_{1}>\delta_{2} \text {. }
$$

Cost minimization will ensure that the net marginal products (NMPs) of the two kinds of capital will be equalized, so that the gross marginal product (GMP) of type 1 capital will exceed the gross marginal product of type 2 capital by the difference in depreciation rates:

$$
\begin{aligned}
& N M P_{1}=G M P_{1}-\delta_{1}=N M P_{2}=G M P_{2}-\delta_{2} \\
& G M P_{1}-G M P_{2}=\delta_{1}-\delta_{2} .
\end{aligned}
$$

A shift in the composition of capital toward assets with larger depreciation rates, represented by a positive increment to type 1 capital $\left(\Delta K_{1}\right)$ and an equal negative increment to type 2 capital $\left(\Delta K_{2}=-\Delta K_{1}\right)$, will indeed result in an increase in gross output, $\Delta G Q$ :

$$
\Delta G Q=\left[\partial G Q_{1} / \partial K_{1}\right] \Delta K_{1}+\left[\partial G Q_{2} / \partial K_{2}\right] \Delta K_{2}=\left[\delta_{1}-\delta_{2}\right] \Delta K_{1} .
$$

21. See Jorgenson, Gollop, and Fraumeni, table 8-8 and accompanying text.

22. This and other issues in evaluating recent trends in capital formation are discussed in Englander and Steindel (1989). 
In accounting for the growth in gross output, therefore, a gross weighting scheme is appropriate. But the added output is equal to the increase in capital consumption allowances. The effect of such a shift in capital composition on net output, $N Q$, is zero because of the equality of net marginal products:

$$
\Delta N Q=\Delta G Q-\left[\delta_{1}-\delta_{2}\right] \Delta K_{1}=0 .
$$

In estimating the effect on output net of depreciation to the growth of net output, the translog index ought to be weighted by the net capital shares.

Since we suspect that most of the capital quality adjustment is the result of differences in gross rather than net marginal products, we conclude that there remains little significant difference between the two studies in determining the capital contribution toward net output growth.

\section{Conclusions}

Where does this leave the assessment of the role of capital? We find that differences in methods used by these two studies do not in fact lead to major differences in estimates of the contribution of capital accumulation to output growth, once we specify what the output is and what kind of capital is being accumulated. If we continue to focus on the old debate, the contribution of business capital to business output, then the main differences between Denison and Jorgenson and his colleagues, aside from the gross-net issue, are: (1) the use by Jorgenson and his colleagues of the translog indexes of capital input, which tends to increase the measured growth of capital services relative to Denison's approach and (2) the Jorgenson assumption of a geometrically declining efficiency of the various capital stocks with age, which appears to reduce the measured growth of capital services relative to the efficiency assumptions made by Denison. On balance, these methodological approaches yield for Jorgenson a 3.5 percent annual growth of capital inputs in the nonresidential business sector compared with a 3.0 percent rise in the Denison estimates. The difference is not trivial, but it is not a huge one either, accounting for a disparity of about 0.1 percent a year in the two estimates of the average capital contribution to gross output over the 1948-79 period. And even this difference would probably be much smaller if net instead of gross returns were used as weights in the translog capital input index. 
From Jorgenson's perspective, there is no question that residential housing and consumer durables are forms of capital, and he can make a case for their inclusion. Moreover, his efforts to use aggregation methods based on a clear theoretical framework are to be applauded. But it is important not to transfer his conclusions to policy discussions that refer to a quite different economic universe than the ones for which they are relevant. In particular, the debate over American competitiveness and lagging growth have not been framed in terms of housing and consumer durables, but usually in terms of the business nonresidential sector where even in the Jorgenson framework the role of capital is much smaller.

\section{Capital-Embodied Technology}

The idea that capital and technology are somehow tied together played a central role in the development of growth and capital theory in the 1960s. The implication is that capital can have a bigger impact on productivity than is indicated by estimates that ignore the linkage. If investing in new capital goods also adds new technology, then investment may have a double benefit. ${ }^{23}$ Is this a valid conclusion?

Models of capital-embodied technical change developed by Solow and others showed how shifting among a range of capital vintages can provide a kind of capital-labor substitution. ${ }^{24}$ But perhaps the biggest surprise, when the full implications of the vintage capital models were worked out, was the demonstration that the steady-state growth rate still remains independent of the rate of capital investment. With the growth in the stock of technology and the growth of the labor force both fixed exogenously, a faster increase in the capital stock this year

23. Richard R. Nelson (1973) has argued that attempts to separate the effect of capital on growth from the effect of technology on growth (as is done in the simple neoclassical model) are futile because the two are inextricably linked. Changing the technique of production (moving around the production function) inevitably involves changes in technology (shifts in the function) when the changes are more than infinitesimal. While we concede the force of Nelson's argument, we believe that some technical changes do not involve capital investments in any major way (the Toyota auto assembly innovations associated with just-in-time inventory methods, for example). Moreover, models of capital-embodied technical change go a long way toward meeting Nelson's objection.

24. Solow (1959). 
will embody more new technology but will reduce the increment to productivity from next year's investment. With embodiment, capital brings new technology into the production process, but the gain is offset by the failure of the new technology to affect the productivity of older capital, which simply becomes obsolete faster.

These results do not dispose of the embodiment issue, however. Analysis by Edmund Phelps demonstrated that investment in new capital, under the embodiment hypothesis, allows an economy to make a more rapid transition to a new steady state than would be the case under the alternative hypothesis of no embodiment. ${ }^{25}$ The possibility that technology may be embodied in capital affects the contribution of capital to growth in an economy that is not operating in the steady-state condition. There are two important growth issues for which the theory of growth with embodiment might shed some light because they do not involve steady-state growth.

\section{Embodiment and the Recent Productivity Slowdown}

In 1981 Martin Baily suggested that the slowdown in productivity growth might have been the result of structural changes in the economy, such as large energy price increases, production shifts necessitated by the expansion of international trade, or other sharp changes in technology or preferences. ${ }^{26}$ If capital goods are designed to maximize profits under a given set of factor and product prices, and if the capital, once produced, is not easily modifiable to operate under another, widely different, configuration of prices, then sharp unanticipated changes in relative prices would increase the rate of obsolescence of capital. A factory designed to produce color televisions in the United States could not easily be converted to produce other products when it became uneconomic to manufacture color televisions here. A factory designed to produce large gas-guzzling autos would operate at a very low level of utilization after the price of energy rose. The argument is that capital that embodies a specific technology may be easily adapted to operate in a moderately altered production setting but not in a radically different

25. Phelps (1962).

26. Baily $(1981,1982)$. 
one. Hence the issue of embodiment may not be terribly important in normal times, but may be in times of major structural change.

The Baily papers used a putty-putty vintage capital model that gave some striking predictions about the way the perfect-foresight market value of capital should respond depending upon what had caused the slowdown in growth. A slowdown caused by a decline in the rate of embodied technological change should raise the real market value of capital. The reason is that the price of old capital will rise relative to new capital because the old capital is at less of a productivity disadvantage. But a slowdown caused by a rise in the rate of obsolescence of old capital should lower the real market value of capital, because of the loss of future quasi rents from prematurely obsolete old capital.

These predictions seemed to indicate that the explanation for the productivity slowdown was a decline in capital services rather than a decline in technological change. The actual market value of capital had fallen substantially over the period of the slowdown. Capital investment had remained fairly strong, despite the fact that the market value of capital was well below its replacement cost (Tobin's $q$ was well below unity). One possible explanation was that new capital was being evaluated very differently from capital already in place.

In terms of the focus of this paper, the model suggested that the productivity of new capital investment would be very high following a bout of accelerated obsolescence because that obsolescence would reduce the effective quantity of old capital, making capital scarcer and its marginal productivity higher. ${ }^{27}$

How has the capital obsolescence hypothesis fared? Not well. In the earlier study, Baily argued that capital input should be measured by an index that was a weighted average of the standard cost-based estimate of the capital stock and the market's valuation of that stock. When capital input is measured this way, its decline (relative to labor input) can explain the fall in labor productivity during 1973-79. But it has not proven to be a good out-of-sample predictor. The market value of capital rose sharply after 1982, with Tobin's $q$ averaging 0.91 in $1987-$ about back to its value in the late 1960s. When incorporated into the index of capital input, it predicts a much more substantial increase in productivity than has occurred. More generally, given the volatility of

27. For this conclusion to hold, it is necessary that the new capital itself not become quickly obsolete. 
the stock market, it is hard to argue that the market value of capital provides an efficient estimate of the true flow of capital services 28

While the recent productivity slowdown may be equally well explained by models that include or exclude the embodiment concept, the two models give very different perspectives on the appropriate policy response to the slowdown. If, under the embodiment cum rapid obsolescence model, the economy has been hurt by a decline in the economic value of its capital, then the appropriate response is to replace the old capital. It would be particularly important to encourage high levels of capital accumulation. But if the slowdown principally reflects a diminished rate of disembodied technological change, the marginal product of capital has declined, and a fall in the rate of investment is ultimately inevitable. The combination of the new, lower rate of technical advance and the old rate of investment will continually push down the return to capital. Many people now writing about the need for increased capital investment sound as if they accept Baily's obsolescence model of the slowdown, even though the evidence for it has not turned out to be very strong.

\section{Embodiment and Catch-Up Growth in Europe and Japan}

Several recent studies have found that in cross-country comparisons the rate of labor productivity growth is much more strongly associated with the rate of capital formation (or the share of investment in GNP) than appears to be consistent with the modest role assigned to capital formation by time series growth accounting studies. A paper by Edward Wolff, both the latest and most comprehensive of these studies, reports two findings relevant to the purpose at hand. ${ }^{29}$ First, among the socalled group of seven major industrial countries (including the United States) the 1950-79 growth of multifactor productivity (constructed with traditional growth accounting weights) is highly correlated with the growth of the capital-labor ratio-that is, the "true" weight assignable to capital in explaining labor productivity growth is higher

28. Hulten and others (1989) have also tested the effect of energy price increases on the obsolescence of some specific capital goods and have not found a major impact.

29. Wolff (1989). 
than the observed property share of capital. Wolff thus finds in the cross-country analysis exactly the opposite of our findings for different time periods within the United States. This international evidence on the effect of capital on growth has been widely cited as showing that increased capital formation can make a major contribution to U.S. growth.

Second, Wolff finds that the growth of both the capital-labor ratio and multifactor productivity is to a high degree inversely correlated with the relative level of multifactor productivity at the beginning of the period-that is, the phenomenon of technological catch-up is most probably playing a role in generating his cross-country results. According to Wolff, his findings suggest that to an important extent technological progress and advances in knowledge must be embodied in capital goods in order to be incorporated into the productive process.

One has to be extremely careful in transferring conclusions about capital's contribution to growth from cross-country studies of Europe and Japan to a country like the United States, which has long been at the technological frontier. The theoretical studies of capital embodiment cited above have shown that if a country is already at the technological frontier, with the stock of available technological opportunities independent of investment activity, the mere fact that some or all of the new technology must be embodied in capital does not increase the longrun rate of growth of output.

In an economy well below the technological frontier the situation is quite different. So long as the education and general skills of the labor force are compatible with what is required by frontier technology, a higher investment share can for a long time generate an increase in the growth rate.

The essential characteristic of catch-up growth is that the backlog of unexploited technological opportunities available to the economy is very large, so that one year's additional "embodying" investment does not significantly eat into that backlog. In the 1950s and 1960s, when European countries were rapidly installing catch-up technology, real interest rates and the real cost of capital remained quite low, and did not rise to ration scarce saving. Rather, financial institutions rationed the available pool of investable funds. If real wages share in the spoils of technological catch-up, so that the profit rates do not fully capture the effects of the rapid embodiment of borrowed technology, then the 
capital "weight" in a standard growth accounting analysis will understate the contribution of capital to the growth process during the catchup period. During the extended period in which catch-up is occurring, a regression of the rate of change of labor productivity on the investment share would show a positive correlation.

As the catch-up is completed, however, the rate of growth of multifactor productivity will be less and less influenced by the share of investment in GNP and at the limit will no longer be affected at all, even though some of the advance of technology at the frontier must still be embodied in capital. The influence of the investment share on the rate of growth of labor productivity will similarly decline toward zero, although the level of labor productivity can, of course, be raised by an increase in the investment share.

\section{An Alternative View of Catch-Up Growth in Europe and Japan}

There is some possibility that during the 1950 s and 1960 s an important element of reverse causation was at work, in which the same large backlogs of catch-up technological progress that generated high rates of multifactor productivity growth also generated high rates of national saving and investment. The conditions that made possible a rapid rate of technological advance also generated high investment shares. Wolff recognizes the possibility of reverse causation and is very circumspect about the claims he makes for his results.

One obvious way in which reverse causality might have occurred is that high rates of income growth could well have led to high rates of net saving. Surprisingly enough, this does not seem to have been a key factor. While experience varied from country to country, private rates of saving declined little, if at all, in the later years of lower growth. It is the case that in Japan and Europe the average national saving rate in the years since 1980 was 4 percentage points lower than it was in the decade of the 1960s. But it was government saving that changed. When investment opportunities were large and growth was rapid, governments found it easier to run balanced budgets or surpluses and did so. But as the backlog of catch-up opportunities began to shrink, and investment opportunities declined, while private saving did not, governments were pressed into pursuing more expansionary fiscal policies, 
which in turn involved a major drop in national saving. It is through government fiscal policy that reverse causality may have occurred and biased upward the investment shares in the cross-section growth studies.

In sum, our argument is that the very large coefficients on the investment share or on the growth of the capital stock in cross-country studies may accurately represent capital's growth contribution in the European and Japanese economies over a certain historical period. But these findings cannot be applied to the U.S. economy. Actually our argument is even stronger. While embodiment may well be important, so that the rate of capital accumulation is more important in a catchup situation than at the frontier, the cross-country studies cited above may overstate the importance of embodiment since they may partly reflect a reverse causal connection-high growth generated high capital formation as well as vice versa.

\section{Imperfect Competition and Capital's Contribution}

How much weight should we give to the argument that the economy departs so far from the assumptions of perfectly competitive conditions that underlie the methodology of the standard growth accounting models that we cannot rely upon their conclusions as to the role of capital in the growth process? The question is complicated in that the two chief imperfections usually cited - those in product markets and those in labor markets-have diametrically opposite implications for growth theory. The existence of pervasive imperfect competition in product markets throughout the economy, with prices above marginal costs, might seem to suggest that the social return to capital formation is less than the private return and that standard growth accounting overstates the historical role of capital in the growth process. And Robert Hall has, we think, convincingly demonstrated that U.S. industries are typically characterized by imperfect product markets and exhibit increasing returns in the short run. ${ }^{30}$ But Hall also argues that, in the long run, there is little evidence of an excess private return to capital. Lawrence Summers has recently reviewed the literature on this point and essentially finds that despite the pervasiveness of imperfectly competitive conditions,

30. Hall (1989). 
the evidence for an excess of private returns over social returns is mixed and inconclusive. ${ }^{31} \mathrm{~A}$ powerful argument against the long-term existence of excess private returns, he notes, is that Tobin's $q$ has averaged less than one over the postwar period, and indeed has exceeded one in only a single very short period.

At the practical level, when Hall adjusted the MFP residual to take account of his own assessment of the effects of market imperfection on income shares, he found that the adjustment did not make much difference. Finally, the BLS has to some extent already been adjusting its income shares in the way that Hall suggests; they estimate the capital share not simply as a residual but adjust it to reflect an independent estimate of the gross rental cost of capital.

On the labor side, Lawrence Katz and Lawrence Summers have argued that labor siphons off some of the quasi rents from capital investment, thus causing the private return from capital to understate the true social return. ${ }^{32}$ They present evidence for the existence of longcontinuing relative wage differentials among industries that apparently cannot be explained by differences in human capital or other characteristics of the workers themselves, and they attribute those differentials both to the existence, in some industries, of monopoly power in the hands of workers, and to efficiency-wage-type phenomena. Katz and Summers show that the industry differentials are positively correlated with the degree of capital intensity. This implies, they argue, that labor is able to expropriate a substantial fraction-20 percent to 40 percent on the basis of their regression-of the incremental return to additional capital intensity. This leads, they say, to an understatement of capital's contribution to growth in growth accounting studies.

The Katz and Summers analysis of wage premiums has implications for theory and policy in a wide range of areas, and this is not the place for a detailed review of their work. But, even granted the existence of persistent industry wage differentials that are correlated with capital intensity, the implications for growth accounting are not all that obvious. One cannot automatically infer from the fact that workers in capital-intensive firms enjoy the benefits of an industrywide wage premium the conclusion that, at the margin, they can extract rents from

31. Summers (1990).

32. Katz and Summers (1989). 
additional investment by individual firms. We might reasonably hypothesize, for example, that efficiency-wage premiums arise from the special need to avoid high turnover and to minimize shirking in industries with an advanced technology. While high technology may, through embodiment, be associated with high capital intensity, this association does not imply that, at the margin, labor can extract some of the return to additional capital formation.

We conclude that the results of Katz and Summers are intriguing and need to be explored further but that they do not yet warrant the assignment of a substantial additional weight to capital in the growth process.

\section{Conclusions}

Three arguments can be used to suggest that physical capital contributes more to average labor productivity growth than the income share of capital indicates. The first is that there are externalities to tangible capital and increasing returns in the production function. There is not much evidence to support this argument; if anything, the weight of the evidence is against it. The second argument is that because new capital embodies new technology and the old capital may be obsolete, capital plays a larger role than its income share implies. The evidence for this view is mainly based on a comparison of countries in a situation of technological catch-up, may be overstated even for those countries, and certainly will not support any policy conclusion based upon it when applied to a frontier economy such as the U.S. economy. The third is that product markets are imperfectly competitive and that labor is able to claim part of the return to capital. The evidence to support the existence of persistent industry wage differentials is pretty strong, but the effect may be more on the allocation of capital by sector than on the overall capital coefficient.

It is not, however, necessary to boost estimates of capital's contribution to growth to justify a shift in current policy with respect to national saving and investment. First, as Summers has shown, there is a substantial gap between the social marginal product of capital and the private rate of return to savers. That suggests an optimal growth 
policy under which the federal budget would be in surplus as long as a surplus is consistent with full employment.

Second, the rate of national saving has fallen since 1980 by more than the warranted rate of investment: Unless we wish to perpetuate the current heavy rate of capital inflow from abroad-which may in any event be impossible - the current rate of national saving will have to rise even to maintain the warranted investment rate. ${ }^{33}$ Moreover, given the demographic projections for the early twenty-first centurywith a large increase in the ratio of retirees to workers-it may be optimal for the nation to aim for a higher output path, with a higher capital-output ratio and a reduced rate of return to capital. ${ }^{34}$ In the transition from here to there, national saving will have to increase. Some of the increase will go toward reducing the inflow of foreign capital; the remainder, to increasing the current rate of (net) domestic investment.

In sum, whatever version of growth theory one accepts-including the most pessimistic one, which blames the productivity growth slowdown on a decline in the technological advance not embodied in capital and which promises only a small additional increment of productivity per increment of capital - a good case can be made for raising the current rate of national investment along with an even larger increase in national saving.

\section{Appendix: Differing Estimates of Output Growth}

The Denison estimate of output growth (3.37 percent a year) is higher than that of Jorgenson, Gollop, and Fraumeni (3.03 percent) and Denison's estimate of employment growth slightly less, so that his labor productivity growth is larger. This means that there is a somewhat greater disparity reported in the two studies in the proportionate contribution of capital-16 percent, as against 26 percent.

The disparity in the two estimates of output growth arises because the implicit price deflator in the Jorgenson estimates rises much more rapidly than the deflator in the official NIPA estimates, which underlie

33. Schultze (1990).

34. Aaron, Bosworth, and Burtless (1989). 
the Denison estimates. We were able to reconcile the Jorgenson and the NIPA estimates of gross domestic product in current dollars very closely for the two endpoint years, 1948 and 1979 (see table A-1). ${ }^{35}$ But on a similar comparison in constant dollars the "nonhousehold" GDP, as estimated by Jorgenson, grew much more slowly than the NIPA over the 31-year period-by 1979 the real output shortfall was 10 percent; correspondingly, the Jorgenson deflator grew by 10 percent more. The annual difference in growth rates is 0.34 percent, exactly the same as the Denison-Jorgenson difference in net output growth shown in table 7 .

The Jorgenson estimates of constant dollar value added were built up by sector from estimates in which the value of deflated intermediate input was subtracted from constant dollar sector output. While the Jorgenson team did, apparently, control to NIPA current dollar totals, the overall consequence of their deflation techniques appears to have been a growth of aggregate value added and the implicit deflator substantially at variance with the NIPA estimates.

35. We first substracted from the NIPA estimates of current dollar GDP the value of indirect taxes (less business property taxes) and military compensation, duplicating adjustments made by Jorgenson, Gollop, and Fraumeni. We then substracted from their total their estimates of value added in the household sector (which consists of the services of consumer durables and owner-occupied housing, plus a small amount for the value of purchased domestic service). The Jorgenson team does not give the value of these three items separately, so we had to subtract the total household sector to arrive at a concept we could match up with the NIPA. The NIPA estimates of GDP do not, of course, include the services of consumer durables, so we subtracted from the NIPA estimates of GDP the other two items included in the Jorgenson team's household sector, using NIPA estimates of their value. The resulting estimates of current dollar "nonhousehold" GDP should be very close. (Jorgenson, Gollop, and Fraumeni make a few small adjustments we did not attempt to duplicate.) And, as shown in table A-1, the estimates were indeed almost identical in the two end-point years. 


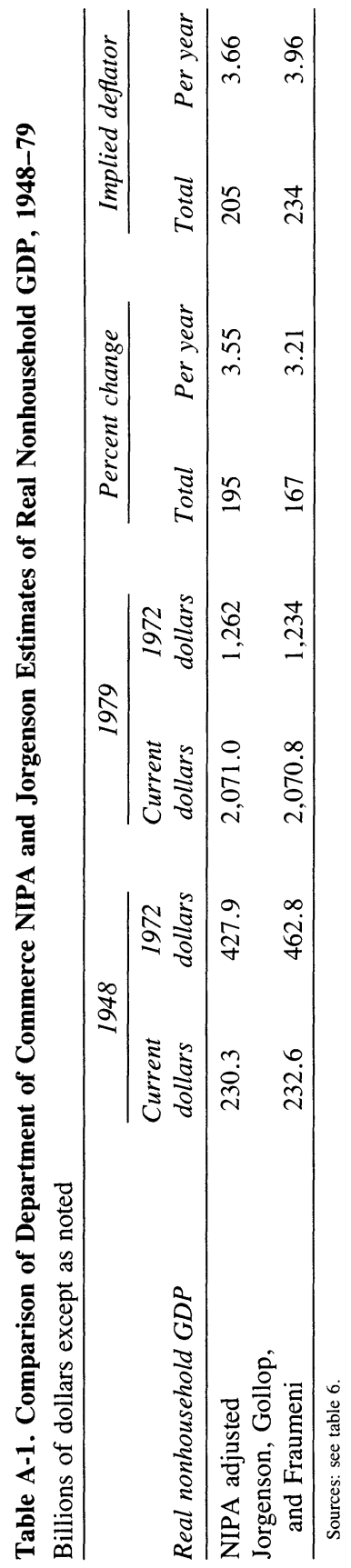




\section{Comments and Discussion}

Comment by Dale W. Jorgenson: In my comments I will evaluate the policy recommendations by Martin Baily and Charles Schultze, using new data on sources of productivity growth. The crucial issue for policy analysis is to distinguish between sources of productivity growth that can be affected by changes in policy and those that cannot be altered by policy. This distinction has been essential to the analysis of productivity growth for three decades. It was introduced by Robert Solow as the contrast between substitution or movements along the production function and technical change or shifts in the production function. ${ }^{1}$

The empirical content of our theory of economic growth has evolved very rapidly during the 1980 s, so that we now have a theory that can serve as an effective guide to policy. Baily and Schultze provide a stimulating discussion of national priorities for economic policy in the introductory and concluding sections of their paper. I can wholeheartedly commend these sections to all readers interested in a sensible view of the priorities. However, I believe that a much more effective case can be made for this view by exploiting three recent innovations in productivity measurement.

The first innovation in the 1980s was the development of efficiency profiles for capital goods by Charles Hulten and Frank Wykoff in research originally sponsored by the Office of Tax Analysis. ${ }^{2}$ The second was the publication of official statistics on multifactor productivity by

1. Solow (1957).

2. Hulten and Wykoff (1981). 
Table 1. Productivity Growth, 1947-85, 1979-85

\begin{tabular}{lccccr}
\hline & \multicolumn{2}{c}{$1947-85$} & & \multicolumn{2}{c}{$1979-85$} \\
\cline { 2 - 3 } $\begin{array}{l}\text { Contributions to } \\
\text { productivity growth }\end{array}$ & $\begin{array}{c}\text { Average } \\
\text { annual } \\
\text { rate }\end{array}$ & $\begin{array}{c}\text { Percent } \\
\text { of total }\end{array}$ & & $\begin{array}{c}\text { Average } \\
\text { annual } \\
\text { rate }\end{array}$ & $\begin{array}{c}\text { Percent } \\
\text { of total }\end{array}$ \\
\hline Growth rate & 2.10 & 100 & & 1.05 & 100 \\
Labor-labor & 0.39 & 19 & & 0.29 & 28 \\
Capital-capital & 0.58 & 28 & & 0.31 & 30 \\
Capital-labor & 0.41 & 19 & & 0.14 & 13 \\
R\&D & 0.25 & 12 & & 0.25 & 24 \\
Residual & 0.46 & 22 & & 0.06 & 6 \\
\hline
\end{tabular}

Source: Jorgenson (1990).

the Bureau of Labor Statistics. ${ }^{3}$ The third was the incorporation of hedonic methods for measurement of capital goods prices into the U.S. national income and product accounts by the Bureau of Economic Analysis. $^{4}$

A summary of U.S. productivity growth that incorporates the innovations of the 1980 s is given in table 1 . The data in the table refer to the U.S. economy as a whole, so that output is defined as gross domestic product. Productivity is defined as output per hour worked. The first row presents the growth rate of productivity, which averaged 2.10 percent a year from 1947 to 1985 . Capital-labor substitution is the contribution of the increase in capital stock per hour worked to the growth in productivity. Labor-labor and capital-capital substitutions are the contributions of substitutions among labor and capital inputs, respectively. $R \& D$ is an estimate of the contribution of investment in research and development to productivity growth through substitution of this form of intangible capital for other inputs. The last row gives the unexplained residual.

The residual in table 1 includes all growth sources not resulting from substitution among inputs. By definition these sources are not responsive to changes in incentives and cannot be affected by economic policy. It is not surprising that the program for research on sources of productivity growth, first articulated by Theodore Schultz, is to move as much of the explanation of productivity growth as possible out of the Solow

4. Bureau of Economic Analysis (1986). 
residual into the category of substitution among inputs. ${ }^{5}$ As a consequence of three decades of active empirical investigation, substantial portions of growth in productivity have been transferred from the residual to the substitution category.

Empirical measurements undergird the assignment of growth sources to any of the four substitution categories in table 1. For example, the contribution of capital-capital substitution is incorporated into the BLS multifactor productivity estimates. Similarly, the contribution of laborlabor substitution, not included in these estimates, underlies the measures of productivity presented in the table. In a paper with Barbara Fraumeni I have constructed empirical estimates of investment in human capital that are comparable to estimates of tangible capital, so that substitution among different types of labor inputs can be treated as a produced source of productivity growth. ${ }^{6}$

Zvi Griliches has provided a range of estimates of the contribution of investment in research and development to growth in productivity, capturing substitution between this form of intangible capital and other inputs. ${ }^{7}$ He gives a high estimate of 12 percent and a low estimate of 6 percent. Incorporating the high estimate in table 1 we can account for 78 percent of productivity growth, leaving only 22 percent as an unexplained residual. It is important to emphasize that this implies that 78 percent of growth can be affected by changes in economic policy, while only 22 percent is unaffected by policy.

Hulten has analyzed substitution among inputs that can be attributed to measures of the output of capital goods, like those of BEA, that incorporate hedonic price indexes ${ }^{8}$ One of the key links between the output of investment goods and capital input is the efficiency profiles for substitution among different vintages of capital goods estimated by Hulten and Wykoff. ${ }^{9}$ A challenge to the approach of Hulten and Wykoff to measuring efficiency profiles was raised by Martin Baily and is reproduced in the paper by Baily and Schultze. ${ }^{10}$ Hulten, James Rob-

\author{
5. Schultz (1961). \\ 6. Jorgenson and Fraumeni (1989). \\ 7. Griliches (1988). \\ 8. Hulten (1988); and Bureau of Economic Analysis (1986). \\ 9. Hulten and Wykoff (1981). \\ 10. Baily (1981).
}


ertson, and Frank Wykoff have confronted the Baily hypothesis with empirical evidence and rejected it. ${ }^{11}$

The estimates of sources of productivity growth given in table 1 have important implications for economic policy. As first-rate policy analysts, Baily and Schultze assign top priority to restoring growth in tangible capital through higher levels of investment. However, they fail to make the most compelling argument for their position, namely, the role of capital input as a source of productivity growth. In table 1 capitallabor substitution accounts for 19 percent of growth, while substitution among different types of capital accounts for 28 percent. Taking capitallabor substitution and substitution among different types of capital together, growth in tangible capital accounts for almost half of growth in productivity.

From 1979 to 1985 the contribution of capital-labor substitution has fallen precipitously to only 0.14 percent a year; it averaged 0.41 a year for 1947-85 as a whole. Capital-capital substitution dropped from 0.58 percent a year for $1947-85$ to only 0.31 percent for $1979-85$. Productivity data incorporating the innovations of the 1980s, like those given in table 1, give persuasive evidence in favor of policies to increase levels of investment in tangible assets. Higher levels of investment promote both capital-labor substitution and substitution among different types of capital; this is precisely the policy recommended by Baily and Schultze.

Surprisingly, Baily and Schultze have devoted much of their paper to an unconvincing attempt to resuscitate the viewpoint on productivity growth associated with Edward F. Denison. ${ }^{12}$ Capital-labor substitution, which Denison includes as a source of productivity growth, accounts for only a relatively modest proportion of growth in productivity. Denison's perspective omits the most important impact of greater investment, namely, substitution among different types of capital. As a consequence, the arguments presented by Baily and Schultze in support of their policy recommendations, which reflect the viewpoint of the 1960 s, are totally unpersuasive. It is clearly important to understand the implications of their unsuccessful attempt to revive Denison's point of view.

11. Hulten, Robertson, and Wykoff (1989).

12. Denison (1962). 
The concept of multifactor productivity used by the BLS can be traced to conceptual developments in the 1940s. However, John Kendrick was the first to provide comprehensive estimates of what was then called total factor productivity. ${ }^{13}$ Unfortunately, Kendrick's work was not properly integrated with the theory of production. Although he incorporated capital-labor substitution or substitution of capital stock for hours worked, this type of substitution accounts for only 19 percent of productivity growth from 1947 to 1985 . He failed to consider substitution among different types of labor and capital inputs. Labor-labor and capital-capital substitution together account for 47 percent of productivity growth.

The publication of official statistics on multifactor productivity was not initiated until 1983, more than two decades after the completion of the initial phase of Kendrick's research. Since this opportunity was finally grasped by the Bureau of Labor Statistics under the leadership of Edwin Dean, Michael Harper, and Jerome Mark, important progress had been made in overcoming the limitations of Kendrick's approach. The first step was taken by Denison. ${ }^{14} \mathrm{He}$ incorporated substitution among different types of labor into productivity measurements by weighting hours worked for each type of labor by wage rates.

Denison's framework for productivity includes capital-labor and labor-labor substitution and accounts for 38 percent of productivity growth from 1947 to 1985 . However, he followed Kendrick in omitting capitalcapital substitution, which is inconsistent with the theory of production. This omission was remedied in my paper with Zvi Griliches. ${ }^{15} \mathrm{We}$ treated capital input in the same way as labor input, recognizing the importance of substitution among different types of capital. To achieve this objective, we weighted different types of capital by rental prices.

The picture of the sources of productivity growth that emerges by combining capital-labor, labor-labor, and capital-capital substitution is totally different from that suggested by Kendrick. Substitution among different types of capital and labor inputs accounts for 67 percent of growth from 1947 to 1985 instead of the 19 percent explained by capitallabor substitution alone. Substitution among different types of labor

13. Kendrick (1956).

14. Denison (1962).

15. Jorgenson and Griliches (1967). 
contributes 19 percent of productivity growth during this period, while substitution among different types of capital inputs accounts for another 28 percent. The obvious conclusion is that Kendrick omitted the most important sources of growth in productivity.

The empirical data on productivity presented in table 1 have completely reversed the conclusion of Kendrick, Denison, and Baily and Schultze that capital is a negligible source of productivity growth. In fact, capital accounts for about half of postwar productivity growth. Estimates based on the methodology of Kendrick and Denison account for around 20 percent. The difference results from the incorporation of all three of the innovations in productivity measurement described abovemeasures of capital input such as those used by BLS, BEA price indexes for capital goods, and Office of Technology Assessment efficiency profiles - into estimates of output, input, and productivity.

To sum up, Baily and Schultze present a reasonable set of policy recommendations in the introductory and concluding sections of their paper. However, they fail to support these recommendations effectively. Like Denison and Kendrick before them, they have failed to integrate their analysis of productivity growth with the theory of production. The remainder of their paper is devoted to a defense of the 1960s view of productivity growth against recent attacks on it by Robert Hall, Paul Romer, and others. Obviously, the most appropriate division of labor is to leave this part of the paper to my fellow discussant, Robert Hall.

Paul Romer's paper is the latest of a serious of insightful models he has developed of important features of the process of economic growth. Romer's program, like that of Schultz, is to transfer growth sources from the Solow residual to produced means of production. As I have already indicated, I view this as a laudable objective. On another occasion I have provided Romer with detailed comments on the proposal he presents in this paper. I hope that he will accept my apologies for not going over this ground again for lack of space.

Comment by Robert E. Hall: My discussion focuses on the substantive economic question of this session: What makes economies grow and what is the role of capital in that process? Although Charles Hulten and Martin Baily and Charles Schultze discuss measurement issues, 
distinguishing shifts of the production function from movements along it, I will confine my remarks to the substantive issue. ${ }^{1}$

Hulten's equation 31 is the right way to think about growth. There is a consumption-possibility frontier over time. Capital enters only as the initial and terminal values. The most general question about capital and growth is, simply, what is the trade-off between consumption now and consumption 25 or 50 years from now? In a neoclassical competitive equilibrium model, the trade-off is not particularly favorable. It is measured directly by the market real interest rate. Diminishing marginal product of capital means that attempts to exploit the trade-off are selflimiting because they make it less favorable. Capital accumulation reduces the real interest rate. Robert Solow's famous theorem that the steady-state growth rate is independent of the saving rate is an application of the self-limiting principle.

The thrust of the paper by Baily and Schultze is to support the general neoclassical conclusion. They note, as many have before, that the direct measured effect of capital on output is around zero. Much recent research on the slope of marginal cost supports this view. Many firms manage their output in such a way as to suggest that they are never constrained by capacity. Baily and Schultze argue that, putting aside special factors holding back less developed countries, there has been a strong convergence to U.S. levels of output per worker. Convergence is precisely the prediction of the neoclassical growth model. They observe that profit rates overstate the return to saving to the extent that measured profit includes monopoly rents. On the other hand, as they also observe, if labor appropriates part of the earnings of capital, profit understates the return to saving. Baily and Schultze counter those who have found that capital inflows to the United States evidence lower earnings of capital in the most capital-intensive country. They believe that ideas other than a rising marginal product of capital schedule can explain this anomaly. Finally, they do acknowledge that there are high excess social returns to research and development, but they do not pursue this point. One finishes the paper with the general feeling that growth is self-limiting in the way expressed in the neoclassical growth model.

1. Charles Hulten presented a paper at the symposium, but it had already been accepted for publication elsewhere. 
Paul Romer stands for the opposite view, that growth rates are endogenous and that growth is not inherently self-limiting. Some endogenous growth models have a property that is the exact opposite of the neoclassical model. Far from being self-limiting, rapid growth becomes self-sustaining once a critical take-off point can be reached. In Romer's way of thinking, the trade-off between present and future consumption is much more favorable to the future. Deferral of consumption generates more $R \& D$, which has a social return in excess of the interest rate. Romer's paper for this meeting is a second generation contribution. It tries to make the endogenous growth model more realistic by modifying some of its assumptions. Although the model has increasing returns, an injection of raw labor has a negative effect on growth and higher saving reduces the rate of return on investment. The new endogenous growth model retains the prominent feature of its predecessors: a strong positive cross-sectional correlation of the growth rate and the investment share of GDP.

As Romer points out, the diminishing marginal products of raw labor and capital mean that something else-production of new techniquesis the engine of long-run growth. Variations across countries in production of new techniques accounts for differences in growth rates. The properties of the model are quite different from those of the neoclassical model.

A chronic problem in this line of thought is why the model applies to national economies. With free trade in intellectual property, there should not be cross-country variations in growth rates. I am not aware that there are or have been important barriers to trade in intellectual property. As a result, I am skeptical about the model's reliance on technical progress as the major source of growth.

I think that agglomeration is an important alternative source of growth that needs more attention in the endogenous growth literature. Ancient Rome achieved consumption levels through agglomeration not exceeded until the last few hundred years. Rome did not have access to technology that was subsequently forgotten. Sheer physical proximity seems to be a key to high productivity. Efficiencies in transportation and, probably more importantly, in coordination, seem to be central to growth. Interestingly, technology that reduces the payoff to proximity-first, the telephone and the train, and more recently, the automobile, the modem, and the fax-have not lowered the payoff to proximity. Rent gradients 
in large cities are as steep as ever. Everywhere in the world where rapid growth occurs, urbanization accompanies it. The specialization that accompanies agglomeration must be an important part of the story.

A good example of the higher productivity achieved with agglomeration is in selling cameras. The clerks in 47 th Street Photo are more than an order of magnitude more productive than those in suburban camera stores. Is it because they have superior technology? Not at all. It is the result of the extraordinarily thick camera market; 47th Street is highly productive because it has so many customers.

Non-neoclassical endogenous growth models are making a lot of intellectual headway these days, and for good reasons. I think the continued exploration of increasing returns, externalities, and other non-neoclassical features will continue to add considerably to our understanding of growth. It remains unclear to me what the role of capital will be in the final story.

General Discussion: William Nordhaus said that a key issue in the symposium was whether the social return on investment is greater than the private return. He said that when the neoclassical model is applied to multifactor productivity growth in the United States since the Great Depression, the results suggest that there may be externalities arising from investment. Nordhaus still wondered, however, if such results arose from spurious causality. He asserted that the gap between the viewpoints of Jorgenson and Baily and Schultze on the share of capital in output and growth was not so significant because with respect to the most important policy issue-the social return to investment-the two positions were relatively close together.

Nordhaus also claimed that if externalities do arise from investment, they are least likely to be found for investments in equipment. Because of the relatively high patentability of equipment, inventors should be able to appropriate more of the returns from investment in this sector than in others.

Edward Denison disagreed with the assessment of Baily and Schultze that technological embodiment was partially responsible for the capacity of European countries to catch up to the U.S. productivity level. He instead ascribed the convergence of European and U.S. labor productivity to other economic changes in postwar Europe, including the re- 
duction of inefficient agriculture and small business and the economies of scale in production that became possible when higher income levels led to an increase in the demand for products with income-elastic demand.

Both Zvi Griliches and Ernst Berndt pointed out the significance of Paul Romer's attempt to connect industrial organization to productivity. Berndt noted that if a monopoly achieves efficiency gains in the production of a good, this might not show up in the price and therefore will not show up as a gain in productivity.

Griliches noted that investment in technology is likely to be driven not only by the real interest rate but also by the likelihood that such investments will pay off in the future. This means, he said, that the current and future macroeconomic situation, which is not accounted for in the models, will greatly affect such investments.

Charles Schultze noted that Romer's paper suggests that all technological advance has to have some resource input. Schultze pointed out that the key question then becomes whether there is any relationship between the quantity of the input and the value of the output. He said that technological advance has been considered exogenous because for a least part of the history of technological advance there was no systematic relationship between inputs and outputs.

\section{References}

Aaron, Henry J., Barry P. Bosworth, and Gary Burtless. 1989. Can America Afford to Grow Old? Brookings.

Abramovitz, Moses. 1956. "Resource and Output Trends in the United States since 1870." American Economic Review 46 (May 1956 Papers and Proceedings, 1955):5-23.

Arrow, Kenneth J. 1962. "The Economic Implications of Learning by Doing." Review of Economic Studies 29 (June):155-73.

Baily, Martin Neil. 1981. "Productivity and the Services of Capital and Labor."' Brookings Papers on Economic Activity 1:1-50.

- 1982. "The Productivity Growth Slowdown by Industry." Brookings Papers on Economic Activity 2:423-54.

Barro, Robert J. 1988. "Government Spending in a Simple Model of Endogenous Growth," NBER working paper 2588. Cambridge, Mass.: National Bureau of Economic Research.

- 1988. "A Cross-Country Study of Growth, Saving, and Government," NBER working paper 2855. Cambridge, Mass.: National Bureau of Economic Research. 
Baumol, William J., Sue Anne Batey Blackman, and Edward N. Wolff. 1989. Productivity and American Leadership: The Long View. MIT Press.

Bureau of Economic Analysis. 1981a. National Income and Product Accounts, 1976-79, Supplement to the Survey of Current Business. Department of Commerce (July).

. 1981b. National Income and Product Accounts of the United States, 1929-76: Statistical Tables, Supplement to the Survey of Current Business. Department of Commerce (September).

- 1986. The National Income and Product Accounts of the United States, 1929-1982: Statistical Tables. Department of Commerce.

Bureau of Labor Statistics. 1983. Trends in Multifactor Productivity, 19481981, Bulletin 2178. Department of Labor.

Dean, Andrew, and others. "Saving Trends and Behaviour in OECD Countries.' Working paper 67. Paris: OECD, table 1.

Denison, Edward F. 1962. The Sources of Economic Growth in the United States and the Alternatives before Us. New York: Committee on Economic Development.

- 1985. Trends in American Economic Growth, 1929-82. Brookings.

Dertouzos, Michael L., Richard K. Lester, and Robert M. Solow. 1989. Made in America: Regaining the Productive Edge. MIT Press.

Dixit, Avinash K., and Joseph P. Stiglitz. 1977. " Monopolistic Competition and Optimum Product Diversity." American Economic Review 67 (June):297308.

Englander, A. Steven, and Charles Steindel. 1989. “Evaluating Recent Trends in Capital Formation.' Federal Reserve Bank of New York Quarterly Review Autumn: 7-19.

Ethier, Wilfred J. 1982. "National and International Returns to Scale in the Modern Theory of International Trade.' American Economic Review 72 (June):389-405.

Freeman, Richard B. 1989. "'Evaluating the European View that the U:S. Has No Unemployment Problem,', NBER working paper 2562. Boston: National Bureau of Economic Research.

Gallman, Robert E. 1966. " Gross National Product in the United States, 18341909.' 'In Output, Employment, and Productivity in the United States after 1800. New York: National Bureau of Economic Research.

Griliches, Zvi. 1979. "Issues in Assessing the Contribution of Research and Development to Productivity Growth.', Bell Journal of Economics 10 (Spring):92-116.

- 1988. "Productivity Puzzles and R\&D: Another Nonexplanation.", Journal of Economic Perspectives 2 (Fall):9-21.

Grossman, Gene, and Elhanan Helpman. 1989a. "Comparative Advantage and Long-Run Growth,' NBER working paper 2809. Cambridge, Mass.: National Bureau of Economic Research.

. 1989b. "Growth and Welfare in a Small Open Economy,', NBER working paper 2970. Boston: National Bureau of Economic Research. 
Habakkuk, H. J. 1962. American and British Technology in the Nineteenth Century. Cambridge University Press.

Hall, Robert E. 1989. “'Invariance Properties of Solow's Productivity Residual,' ' working paper 3034. Cambridge, Mass.: National Bureau of Economic Research (July).

Hulten, Charles R. 1979. "'On the 'Importance' of Productivity Change.', American Economic Review 69 (March):126-36.

. 1989. "Capital and Technology: A Reclassification of the Sources of Growth." Unpublished Manuscript, University of Maryland, Department of Economics.

Hulten, Charles R., and Frank C. Wykoff. 1981. “'The Estimation of Economic Depreciation Using Vintage Asset Prices: An Application of the Box-Cox Power Transformation.', Journal of Econometrics 15 (April):367-96.

Hulten, Charles R., James W. Robertson, and Frank C. Wykoff. 1989. “Energy, Obsolescence, and the Productivity Slowdown.' In Technology and Capital Formation, edited by Dale W. Jorgenson and Ralph Landau. MIT Press.

Jorgenson, Dale W. 1990. "Productivity and Economic Growth." In Fifty Years of Economic Measurement: The Fiftieth Jubilee Volume of the Conference on Research in Income and Wealth, edited by Ernst R. Berndt and Jack E. Triplett. University of Chicago Press.

Jorgenson, Dale W., and Barbara M. Fraumeni. 1989. "The Accumulation of Human and Nonhuman Capital, 1948-1984.' In The Measurement of Saving, Investment, and Wealth, edited by Robert E. Lipsey and Helen S. Tice. University of Chicago Press.

Jorgenson, Dale W., Frank M. Gollop, and Barbara M. Fraumeni. 1987. Productivity and U.S. Economic Growth. Harvard University Press.

Jorgenson, Dale, and Zvi Griliches. 1967. "The Explanation of Productivity Change.' Review of Economic Studies 34 (July):249-83.

Katz, Lawrence F., and Lawrence H. Summers. 1989. "Industry Rents: Evidence and Implications." Brookings Papers on Economic Activity: Microeconomics, 1989:209-90.

Kendrick, John W. 1961. Productivity Trends in the United States. Princeton University Press.

Lucas, Robert E., Jr. 1988. "'On the Mechanics of Economic Development.", Journal of Monetary Economics 22 (July):3-42.

Nelson, Richard R. 1973. "Recent Exercises in Growth Accounting: New Understanding or Dead End?' American Economic Review 63 (June):46268.

Nelson, Richard R., and Sidney C. Winter. 1982. An Evolutionary Theory of Economic Change. Harvard University Press.

Nordhaus, William D. 1972. “The Worldwide Wage Explosion.' Brookings Papers on Economic Activity 2:431-64.

Phelps, Edmund S. 1962. “'The New View of Investment: A Neoclassical Analysis.'" Quarterly Journal of Economics 76 (November):548-67. 
Rivera-Batiz, Luis A., and Paul M. Romer. 1989. “'International Trade with Endogenous Technological Change." Unpublished manuscript. University of Chicago.

Rothbart, Erwin. 1946. "Causes of the Superior Efficiency of U.S.A. Industry as Compared with British Industry.' ' Economic Journal 56 (September):38390.

Romer, Paul M. 1986. “'Increasing Returns and Long-Run Growth,' Journal of Political Economy 94 (October):1002-37.

. 1987a. "'Growth Based on Increasing Returns Due to Specialization,', American Economic Review (Papers and Proceedings, 1986) 77 (May):5662.

1987b. "Crazy Explanations for the Productivity Slowdown." NBER Macroeconomics Annual 2:163-202.

. 1989a. "'Measurement Error in Cross-Country Data.' Unpublished manuscript, University of Chicago, Center for Advanced Study in the Behavioral Sciences.

1989b. "Increasing Returns and New Developments in the Theory of Growth." Working paper 3098. Cambridge, Mass.: National Bureau of Economic Research (September).

- 1990a. “Endogenous Technological Change.' Journal of Political Economy.

- 1990b. "Capital, Labor, and Productivity." Brookings Papers on Economic Activity: Microeconomics, forthcoming.

Schultz, Theodore W. 1961. "'Investment in Human Capital.' American Economic Review 51 (March):1-17.

Schultze, Charles L. 1987. ' Saving, Investment, and Profitability in Europe.' In Barriers to European Economic Growth: A Transatlantic View, edited by Robert Z. Lawrence and Charles L. Schultze. Brookings.

_. "Setting Long-Run Deficit Reduction Targets: The Economics and Politics of Budget Design.', In Social Security and the Budget, edited by Henry J. Aaron. Washington: University Press of America.

Shell, Karl. 1966. "Toward a Theory of Inventive Activity and Capital Accumulation.', American Economic Review: 56 (May 1966, Papers and Proceedings, 1965):62-68.

- 1967. "A Model of Inventive Activity and Capital Accumulation.', In Essays in the Theory of Optimal Economic Growth, edited by Karl Shell. MIT Press.

Sokoloff, Kenneth L. 1988. "Inventive Activity in Early Industrial America: Evidence from Patent Records, 1790-1846." Journal of Economic History 48 (December):813-50.

Sokoloff, Kenneth L. and B. Zorina Khan. 1990. "The Democratization of Invention during Early Industrialization: Evidence from the United States.', Journal of Economic History.

Solow, Robert M. 1956. "A Contribution to the Theory of Economic Growth.", Quarterly Journal of Economics 70 (February):65-94. 
1957. "Technical Change and the Aggregate Production Function." Review of Economics and Statistics 39 (August):312-20.

. 1960. "Investment and Technical Progress." In Mathematical Methods in the Social Sciences, 1959, edited by Kenneth J. Arrow, Samuel Karlin, and Patrick Suppes. Stanford University Press.

Summers, Lawrence. 1990. "What Is the Social Return to Capital Investment?' In Essays in Honor of Robert Solow, edited by Peter Diamond. MIT Press (forthcoming).

Summers, Robert, and Alan Heston. 1988. “A New Set of International Comparisons of Real Product and Price Levels Estimates for 130 Countries, 19501985,' Review of Income and Wealth 34 (March):1-25.

Wolff, Edward N. 1989. "Capital Formation and the Productivity Convergence." Mimeo. New York University (January). 